\title{
Jette Holm og Elisabeth A. Glenthøj i samarbejde med Christian Thodberg, N. F. S. Grundtvig: Prædikener i Vartov 1842-45
}

\section{Af Hans Raun Iversen}

N. F. S. Grundtvig: Proedikener i Vartov 1842-45, bind 5-7, udgivet af Jette Holm og Elisabeth A. Glenthøj i samarbejde med Christian Thodberg, samt Bind 8, Christian Thodberg, Indledning og kommentarer til Grundtvigs proedikener $i$ Vartov 1842-45 (bind 5, 6 og 7). Forlaget Vartov, København 2007, 381 s. (bind 5), 412 s. (bind 6), 413 s. (bind 7) og 459 s. (bind 8).

"Der er tilstrækkeligt materiale for andre til at fortsætte det arbejde, som hermed er begyndt". Med denne gode opfordring og jyske underdrivelse (både med hensyn til hvad der er gjort, og hvad der fortsat kan gøres) slutter Christian Thodberg forordet til sit kommentarbind til de sidste tre årgange (1842-45) af de i alt 20 årgange Grundtvig-prædikener fra perioden 1821-45, som Thodberg siden 1983 har fået udgivet sammen med sine gamle elever fra teologistudiet i Århus. Fremgangsmåden er den samme i alle bind: Først renskrivning af Grundtvigs manus med alle varianter, markeringer etc., fremlagt i ringbind, som kan studeres på Grundtvig Centeret i Århus, hvor der i øvrigt også findes udskrifter af prædikenerne 1845-49. Så udgivelse af den tekst, som "efter bedste skøn" er den, Grundtvig har haft med sig på prædikestolen. Og så ligesom for de første tre årgange Vartov-prædikener et bind med fortløbende, kommenterende gennemgang af tre årgange prædikener ved Christian Thodberg. Det er alt sammen meget prisværdigt, og det så meget des mere i kraft af, at der har skullet kæmpes med at finde fonde til at betale trykkeriregningen.

Også som prædikant er Grundtvig sin egen. Om han er værre eller bedre end sine samtidige, er noget af en smagssag. At læse hans prædikener uden at have hørt dem eller på anden måde været tæt på den eksistentielle situation, er omtrent som at læse andre præsters prædikener. Indimellem prædiker tekst og prædikant derudaf - men pludselig må man så alligevel spidse ører - eller øjne. Prædikenerne har sjældent samme teologiske præcision som skrifterne - og langtfra samme sproglige prægnans som salmerne. De er primært sermoner, opbyggelig og oplysende forkyndelse for de kære Kristi venner i Vartov kirke. Derfor er der ikke megen dogmatisk drøftelse eller for den sags skyld polemik mod dette eller hint i samtiden, men en stadig strøm af forsikringer om alt det gode, som Vorherre har i sinde med os. I al deres 
massivitet er prædikerne dog afgørende som kilder til mangt og meget. Måske først og fremmest til Grundtvigs hele før-sekulære kristendomssyn, som - alle sindssvingninger til trods - fastholdes og hamres ind ved at gentages igen og igen. Men naturligvis også til en lang række teologiske temaer, som man kan undersøge på kryds og tværs i prædikenerne. Hertil kommer muligheden for at følge Grundtvigs liv og arbejde så at sige dag for dag. Ikke mindst dette perspektiv har Thodberg stadig for øje, når han gennemgår prædikenerne med inddragelse af tematisk og tidsmæssigt relevante salmer, skrifter samt andre kilder som brevvekslinger og erindringerne - samt naturligvis Adresseavisens prædikantlister.

En god prøve på Grundtvig som prædikant og menighedskristen leverer prædikenerne fra tiden omkring krisen i forbindelse med fåresygen $\mathrm{og}$ den efterfølgende depression i foråret 1844 . Selv om Grundtvig er udmattet og stillejet mindre højt end til andre tider, er det grundlæggende kristendomssyn i prædikenerne det samme. Den krisestemning, som andre kilder belyser, tager Grundtvig ikke med sig på prædikestolen - endsige i liturgien og sakramentsfejringen. Gudstjenesten med dens mundsord er urokkelig - Guds anden skabelse i mundsordenes virke er selve betingelsen for det kristne liv, akkurat som den første skabelse er det for menneskelivet. Men formerne er ikke derfor underordnede. Det ved Grundtvig fra sig selv. I et brev af 19. maj 1843, forud for Englandsrejsen, skriver han til Gunni Busck: "Kan Du komme herind, før jeg reiser, saa giør det, for jeg længes efter den Hellige Nadver og synes dog ikke, at jeg har Glæde af at nyde den hos dem, der forrette den ligesom Jordspaakastelse" (kommentarbindet s. 89). Thodberg benytter som forventeligt flere steder lejligheden til at returnere debatten omkring Grundtvigs nadversyn, som han selv indledte med sin nadverafhandling fra 1975 (s. 172-173). Uden forståelse for den hovedsag i den kirkelige anskuelse, at ordet er legemligt, at Kristus er fuldt og helt og dermed også legemligt tilstede i og med sine mundsord ved sakramenterne (jf. også Thodbergs note 92, s. 185), forstår man ikke Grundtvigs syn for realpræsensen i nadveren - eller i barnekammeret og ægteskabet for den sags skyld.

Efter disse eksempler på, hvor den teologiske opmærksomhed må vågne ved læsningen af prædikenerne - og $\mathrm{i}$ hvert fald, når de sammenholdes med Thodbergs kommentarer, skal jeg vende tilbage til det mest spændende forløb i de tre år, kriseforløbet i foråret 1844. Meget har været fremlagt før, men nu får vi den fortløbende fremstilling $\mathrm{i}$ kraft af prædikerne og Thodbergs kommentarer. Midt i det hele kommer der et klassisk stykke thodbergiana i form af en ekskurs side 201224 om tilblivelsen af Sov sødt, barnlille, hvor det afgørende især er fremhævelsen af Grundtvigs dybdeerfaring af realpræsensen i Fader- 
vor, der overdrages ved dåben og frit bruges i barnekammeret og $\mathrm{i}$ øvrigt overalt, som nu eksempelvis i Grundtvigs depression. Lidt tilfældigt læste jeg Thodbergs ekskurs om Sov sødt, barnlille i forlængelse af en genlæsning af Peter Balslev-Clausens lige så grundige undersøgelse af tilblivelsen af kroningen af Grundtvigs og Maries kærlighed i salmen Urolige Hjerte! (Hymnologiske Meddelelser 3-4/ 1991). Også her handler det om realpræsensen, nemlig om den sikre erfaring af, at Maries og Grundtvigs kærlighed virkelig er fra Gud og derfor 100 procent kristeligt valid og trøsterig for det religiøst urolige hjerte. Og igen har vi et udtryk for, hvordan Grundtvigs bedste salmer begynder som et stykke ubeskyttet personlig bekendelseslitteratur, som så efterhånden finder et alment udtryk, som kan blive stående som fælles menighedssalme. Og igen finder inkarnationen sted på ny i kraft af realpræsensen i Grundtvigs erfaring, som finder nedslag i den nye salme. Men igen gælder det også, at Gud er Gud, og Gud er god, så at sige uafhængigt af Grundtvigs personlige kamp for at få hold på og udtrykke sin personlige erfaring af Guds nærvær. På den måde står Grundtvig solidt plantet midt mellem den førmoderne Peter Dass og vi andre senmoderne, forbeholdent troende.

Uden (Jomfru) Marie ingen inkarnation, uden hende ville Jesus være et tankefoster og just ikke sandt menneske. Det understreger Grundtvig igen og igen, blandt andet Mariæ Bebudelsesdag i 1844. Uden en lige så konkret Marie (Toft)-kærlighed kan Grundtvig heller ikke fastholde livsfølelsen og dermed sikkerheden i det kristne liv. Så konkret Guds kærlighed end rækkes os i dåbens vand og nadverens brød og vin i kraft af de dermed forbundne ord af Herrens egen mund, så vanskeligt er det dog for Grundtvig at leve af og med Guds kærlighed i sakramenternes skikkelse alene. Det bliver klart i kriseforløbene 1844 og 1851 - eller kriseforløbet 1844-1851! Også for at der kan kastes endnu mere lys over dette lange forløb og dermed den dybe sammenhæng mellem det kristelige og det menneskelige i Grundtvig liv og tækning, må man håbe, at nogen vil tage Thodbergs handske op og fortsætte udgivelsen af Grundtvigs Vartov prædikener!

Skulle jeg endelig anmelde en enkelt indvending mod Thodbergs kommentarer, vil jeg gribe fat $i$ hans sidste note, hvor han karakteriserer Grundtvigs betegnelse af trosbekendelsen (i prædiken til sidste søndag i kirkeåret 1844-45) som "et Ord af Herrens egen Mund" som "Et sjældent vidnesbyrd i prædikenerne om den kirkelige anskuelse". Det er rigtigt, at Grundtvig sjældent direkte prædiker om sit kirkesyn akkurat som en bibelkristen prædikant vel også sjældent vil bruge prædikenen til at argumentere for sit bibelsyn. Kirke- og bibelsyn prædiker man ud af - ikke om! Ikke desto mindre gør Grundtvig det indimellem, for eksempel i den markante og følelsesladede ("majestæ- 
tisk", kalder Thodberg den) afskedsprædiken til menigheden i Vartov onsdag den 1. maj 1844 før sin bortrejse på grund af depressionen: Hvad Grundtvig har at trøste sig selv og sin menighed med, er just mundsordene ved dåb og nadver, som just han selv opdagede dem så mageløst! Med de ord i menighedens mund kan prædikanten sige fortrøstningsfuldt farvel - for menighedens liv og tro beror på mundsordene, og just ikke på præstens prædiken (jf. også for eksempel prædikenen til 26. søndag efter trinitatis 1845). Thodberg ser og ved dette så godt som nogen. Ikke desto mindre har han - ligesom resten af det 20. århundredes dialektisk teologisk påvirkede forkyndelsesteologer svært ved at fastholde, at sådan er det overalt hos Grundtvig - både i hans salmer, skønt vi synger hen over det, og i hans prædikener, skønt vi vanskeligt hører, at Grundtvig altid (siden ca. 1825) vidner ud af og for så vidt også om - sin kirkelige anskuelse. 